\title{
Analysis of Factors that Influence Dividend Payout Ratio of Coal Companies in Indonesia Stock Exchange
}

\author{
Pradana Jati Kusuma ${ }^{1} \bowtie$ Sri Hartoyo $^{2}$, Hendro Sasongko $^{3}$ \\ School of Business, Bogor Agricultural University, Bogor, Indonesia ${ }^{1}$ \\ Faculty of Economics and Management, Bogor Agricultural University, Bogor, Indonesia ${ }^{2}$ \\ Faculty of Economics, Pakuan University, Bogor, Indonesia ${ }^{3}$
}

Info Article

\section{History Article:}

Received 17 August 2018

Approved 8 September 2018

Published September 2018

Keywords:

Dividend Payout Ratio; Coal;

Dividend Policy.

\begin{abstract}
The purpose of this study is to analyze the company's internal and macroeconomic conditions on the ratio of dividend distribution, as well as knowing the conditions of coal companies on the IDX during the decline in coal prices. The weakening of the global economy has resulted in a decline in various commodity prices, including coal prices. Various studies were conducted to determine the factors that influence the poor condition of sectoral mining indices in these weakening conditions a few years ago. The coal subsector has the largest capitalization in the mining sector. Multiple regression models are used to analyze 55 samples from 11 coal subsector companies. The research period was carried out from 2013 to 2017. The results showed that return on assets, exchange rates, world oil prices had a positive and significant partial effect on the dividend payout ratio of the coal subsector. The implications of the findings are management of coal subsector company needs to pay attention to internal and external factors so that they can distribute dividends regularly.
\end{abstract}

\section{Analisis Faktor-Faktor yang Mempengaruhi Dividend Payout Ratio Perusahaan Batubara di Bursa Efek Indonesia}

\begin{abstract}
Abstrak
Tujuan penelitian ini untuk menganalisis kondisi internal perusahaan dan makroekonomi terhadap rasio pembagian dividen, serta mengetahui kondisi perusahaan-perusahaan batubara di BEI selama penurunan harga batubara. Pelemahan ekonomi global mengakibatkan penurunan berbagai harga komoditas, termasuk harga batubara. Berbagai penelitian dilakukan untuk mengetahui faktor yang mempengaruhi kondisi buruk indeks sektoral pertambangan dalam kondisi pelemahan ini beberapa tahun lalu. Subsektor batubara memiliki kapitalisasi terbesar pada sektor pertambangan. Model regresi berganda digunakan untuk menganalisis 55 sampel dari 11 perusahaan subsektor batubara. Periode penelitian dilakukan dari 2013 hingga 2017. Hasil penelitian menunjukkan bahwa return on assets, nilai tukar, harga minyak dunia memiliki pengaruh positif dan signifikan parsial terhadap dividend payout ratio subsektor batubara. Implikasi dari temuan ini adalah bahwa manajemen perlu memperhatikan faktor internal dan eksternal sehingga manajemen dapat membagikan dividen secara rutin.
\end{abstract}

JEL Classification: G3, G34

How to Cite: Kusuma, P. J., Hartoyo, S., \& Sasongko, H. (2018). Analysis of Factors that Influence Dividend Payout Ratio of Coal Companies in Indonesia Stock Exchange. Jurnal Dinamika Manajemen, 9(2), 189-197. 


\section{INTRODUCTION}

Coal is the third largest fossil energy contributor after oil and gas. Coal does not require special processing like other fossil energy. Indonesia is one of the Indonesia-investments suppliers. This is indicated by the average value of Indonesian coal exports reaching 78.89\%, equivalent to $351 \mathrm{MT}$ in 2013 to 2017. This indicates that the coal business is oriented to the export market. The mining sector has a capitalization of $4.80 \%$ of the total market capitalization on the Indonesia Stock Exchange in 2017. The coal subsector has a capitalization of $69.59 \%$ of all capitalization in the mining sector. This explains that the coal subsector is a driver of the sectoral mining index. The coal price movement since 2011 has continued to decline until mid-2016. The price of Australian thermal coal has decreased from USD 132.48/ Metric Ton in January 2011 to USD 50.71/ Metric Ton in February 2016. This is due to the weakening of the global economy.

After the 2008 crisis, the economies of developed countries did not improve as expected, for example, America, Japan and European countries. The global economy is transitioning from the Atlantic to the Pacific. China has been the driving force of the global economy in recent years, but China has begun to change its policies. As a result, the global economy is getting sluggish and prices of various commodities have dropped dramatically, including coal. This weakening will cause funding problems that can affect the company's financial condition (Fatoni et al., 2013). This will have an impact on dividend distribution or returns expected by investors.

Dividend policy is a company decision in determining the amount of profit to be distributed in the form of dividends or retained earnings for future investments. The importance of dividends has been substantially proven in the dynamics of the stock market. A company that consistently increases dividend payments shows a clear indication that the company is stable and has many profits, so it is less likely to be threatened by market uncertainty and economic downturn. In 2016, the total profits of coal companies at the Indonesia Stock Exchange reached USD 783 million with a dividend of $30 \%$. In the following year, this portion decreased to $21 \%$ with total profits reaching USD 1.733 million. According to Baah et al. (2014) profitability has a positive effect on increasing the dividend distribution ratio. The change in the ratio of dividend distribution (in this case decreases with increasing profits) in the coal subsector company is a consideration for research.

Dividends have or contain information as a condition of the company's prospects. Companies must set dividends appropriately because they affect stock prices, asset prices, capital structure, mergers, acquisitions and capital budgeting. Decreasing or eliminating dividends can indirectly show the performance of companies experiencing financial problems (Bhattacharya, 1979; Waseem et al., 2011; Prasetyo, 2013).

According to the bird in hand theory by Gordon and Lintner (1956) states that investors prefer dividends because they are considered more specific than capital gains. This causes investors to prefer dividends that are definitely nominal rather than capital gains which may still change in nominal value. Based on the concept of time value of money, dividends paid by companies now have a higher value than expected future capital gains. Based on this concept, it can be explained that the higher the dividends paid by the company, the higher the investor's interest in investing in the company. This will cause dividends to affect stock prices or company value (Fenandar, 2013; Abiprayu \& Wiratama, 2016). Dividends are a form of appreciation from management to shareholders and the distribution is different in number for each company.

The main aspect of dividend policy is determining the right cost between dividend payments and additional profits that will be held by the company. Sudana (2011) states that divi- 
dend policy is related to the number of dividend payout ratios, which are net income from dividends to shareholders. Brigham and Houston (2012) states that there are three dividend policy theories from investor preferences, namely irrelevant dividend theory, bird theory in hand and tax preference theory.

According to Gordon and Lintner (1956) the cost of own capital will increase if the ratio of dividend payments is low. Investors prefer to receive dividends from capital gains. This is because the dividend is a factor that can be controlled by the company while the capital gain is a factor used by the market. Miller and Modigliani (1961) assumed that the arguments put forward by Gordon and Lintner (1956) were errors. Miller and Modigliani (1961) stated that investors would choose to reinvest the dividends they produce at the same company or in companies that have almost the same compensation. What is sought by companies whose members are companies for $\operatorname{tax}$ (EAT) in the form of dividends.

Previous research found that profitability, company size and equity obtained had a positive and significant influence on dividend payment policies (Frangky, 2015). Dividend policy has a positive relationship with size, current profit, liquidity and has a negative relationship with leverage, growth, free cash flow, economic conditions (Jabbouri, 2016). Many of the studies concluded that dividend payment behavior in developing countries is different from developed countries. Some factors that contribute are perceptions, culture, market size, market depth, efficiency, regulations and taxation (Maldajian \& El Khoury, 2014).

The novelty of the present study is that this study determines the effect of company characteristics and macroeconomic factors on dividend policy in coal subsector companies in Indonesia. The dividend payout ratio is used as a proxy for dividend policy. The company to be studied is a coal subsector company registered from 2013 and the period under study in 20132017. Coal is the largest fossil energy contributor and Indonesia is one of the investment suppliers.

\section{Hypothesis Development}

Relationship between Return on Assets and Dividend Payout Ratio

Asset returns are met on profitability and operational efficiency. This ratio is used to measure the ability to generate profits by using the current amount and costs used for analysis. Returns on positive assets indicate companies that provide profits for the company, and vice versa. Therefore, a higher return on assets allows companies to prosper shareholders. Some studies show a positive relationship between return on assets and dividend distribution ratio (Oza, 2004; Kang et al., 2010; Booth \& Zhou, 2017). Based on the previous studies, the following hypothesis can be structured:

$\mathrm{H} 1$ : Return on assets has a positive effect on the dividend payout ratio.

\section{Relationship between Debt to Equity Ratio and Dividend Payout Ratio}

Debt to equity ratio is one of the financial ratios belonging to the group of solvency ratios. This debt ratio measures the financing of a company from a source of debt which will have an impact on obligations or fixed expenses. Debt to equity ratio is used to measure the level of use of debt to the total equity of shareholders owned by the company. The higher the ratio, the lower the corporate funding provided by shareholders. In perspective, the ability to pay long-term obligations, the lower the ratio, the better the company's ability to pay its long-term obligations. According to several studies, the coefficient between the dividend distribution ratio and the debt ratio shows a negative relationship (Al-Twaijry, 2007; Deshmukh et al., 2013; Strebulaev \& Yang, 2013). Therefore, the following hypothesis can be structured:

$\mathrm{H} 2$ : Debt to equity ratio has a negative effect on the dividend payout ratio.

\section{Relationship between Freecashflow and Divi- dend Payout Ratio}

Free cash flow is the result of the calculation of cash produced by the company during financial times after operating costs and capi- 
tal expenditure to develop its business. Free cash flow is the excess cash needed to fund all projects that have a positive net present value after dividing dividends (Jensen, 1986). Management cannot use money freely because this money can be used to develop business or as dividend feed for shareholders. Alli et al. (1993) argue that dividend payments are more in cash flow, which reflects the company's ability to pay dividends, the current amount of income, which is not much by accounting. Some studies show a positive relationship between cash flow and dividend distribution (Kalcheva \& Lins, 2007; Officer 2011; Muhlhofer \& Andrey, 2012). Based on the previous studies, the following hypothesis can be structured:

H3: Free cash flow ratio has a positive effect on the dividend payout ratio.

\section{Relationship between Company Size and Divi- dend Payout Ratio}

Company size is one aspect of dividend payments. Total revenue can also be used to measure the size of the company. Research on company size can use the benchmark of assets. If the company is large, then the opportunity to distribute dividends will be even higher. This is because companies can use these assets to make profits. The larger the size, the greater the information available to the public. Research produces a relationship between size and dividend distribution ratio (Lee et al., 2013; Nurhayati, 2013; Putri, 2013). This happened to the performance of large companies for small companies. Therefore, the hypothesis is:

H4: Company size has a positive effect on the dividend payout ratio.

\section{Relationship between Company Age and Divi- dend Payout Ratio}

The age of the company is the length of a company starting when standing, developing and surviving. The age of the company is calculated since the company was established based on the deed of the establishment until the research was conducted. Beatty (1989) study's sta- tes that companies that have been established for a long time are likely to have had much experience. The longer the age of the company will provide a lot of information to the public about the company. This will lead to consumer confidence in the company's products. The more mature a company is, the greater the possibility of dividends being distributed. Some studies suggest a positive relationship between company age and dividend distribution ratio (Darmawan, 2008; Nurhayati, 2013; Takhtaei \& Tamimi, 2014). Therefore:

H5: Company age has a positive effect on the dividend payout ratio.

\section{Relationship between Exchange Rate and Divi- dend Payout Ratio}

The exchange rate has a considerable influence on the current account balance or other macroeconomic variables. The exchange rate is the relative price of a currency against the value of another currency (Moosa, 2004). In companies that carry out import and export transactions in the event of exchange rate depreciation can affect the company. This will cause the company's financial risk to increase so that share prices and company profits will decline. As a result of this depreciation, the export volume increased, the company's cash flow also increased. The coal subsector company is a company with an export market orientation so that when there is a weakening or the exchange rate of the $\mathrm{Ru}$ piah against the Dollar increases, it will affect the increase in the dividend distribution ratio (Saeed et al., 2014; Nuhu, 2014; King'wara, 2015). Therefore, the hypothesis is:

H6: Exchange rate has a positive effect on the dividend payout ratio.

\section{Relationship between Oil Price and Dividend Payout Ratio}

The price of world crude oil is determined based on the balance between oil supply and demand in the world. The increase in oil prices in general has driven up other commodities such as mining. This certainly results in the company 
having the potential to make a profit. McSweeney and Worthington (2008) state that oil price movements have a positive effect on the energy industry while in other industries such as banking, retail and transportation have a negative relationship. Oil price has a positive effect on the dividend payout ratio (Sim \& Zhou, 2015; Reza et al., 2016). Therefore, the hypothesis is: H7: Oil price has a positive effect on the dividend payout ratio.

\section{Relationship between Commodity Pricess and Dividend Payout Ratio}

Commodity prices are based on prices of each business actor. Coal is one component that affects the weakening of the global economy. Coal companies in Indonesia change in the export market. Price changes due to declining global coal demand will have an impact on coal companies in Indonesia. On the contrary, reducing the number of exports will affect the company's income (Eko et al., 2013). Commodity prices hava a positive effect on the dividend payout ratio (Abhyankar et al., 2013; Majanga, 2015). Therefore, the hypotheis is:

H8: Commodity prices have a positive effect on the dividend payout ratio.

\section{METHOD}

The object of the research is 11 companies from 24 coal sub-sector companies. This research used descriptive analysis and simple panel data regression analysis. Data is obtained from the company's annual report and the annual report of the Indonesian stock exchange (IDX).

The variables to be analyzed in this study are the variables of company characteristics and macroeconomics that will be seen in terms of their influence on dividend policy in the company. The variables used in this study refer to previous studies. The hypothesis in this study is generally used to examine the influence of moderating variables on the independent variable with the dependent variable in the model of the equation.

\section{RESULT AND DISCUSSION}

Table 1. Descriptive Statistic on Coal Sector Companies in 2013-2017 ( $\mathrm{N}=55)$

\begin{tabular}{crrrr}
\hline Variables & Mean & Maximum & Minimum & Std. Dev \\
\hline DPR & 33.4 & 127.6 & 0.0 & 32.7 \\
ROA & 8.5 & 39.3 & -16.3 & 2.4 \\
DER & 88.3 & 444.8 & 10.8 & 30.0 \\
FCF & 12.3 & 104.2 & -10.7 & 10.8 \\
SIZE & 20.1 & 22.6 & 18.4 & 0.0 \\
AGE & 3.0 & 3.8 & 1.8 & 0.1 \\
KURS & $12,525.9$ & $14,650.0$ & $9,663.5$ & $1,270.0$ \\
OIL & 66.9 & 107.7 & 33.6 & 24.8 \\
HKM & 73.3 & 102.1 & 49.8 & 15.1 \\
\hline
\end{tabular}

Table 1 presents the descriptive analysis of the characteristics of the company and the macroeconomic of the coal subsector company during the 2013 to 2017 study period including the average value, maximum value, minimum value, and level of deviation. It presents the calculated values for each research variable to find out the distribution of data before further research is conducted.

\section{Descriptive analysis}

The movement of the Australian coal price index (Barlow Jonker Index) FOB Newcastle has become a reference for coal prices in Asia, including Indonesia. Although there were changes with the emergence of the Indonesian Coal Index (ICI) in 2006 and the Reference of Coal Prices (HBA used four reference indices, namely ICI, PI, GC and NEX) in 2009, the Australian coal price index was still in use.

The average dividend payout ratio is 33.4. This shows that the amount of dividends paid is $33.4 \%$ of the total profit of the coal subsector. That is, the remaining profits generated by coal companies are used for company development or operational financing. The return on assets ratio is in bad condition, because of the debt ratio increases. The mean return on assets below 1 indicates that the company's profitability is considered unhealthy.

The debt to equity ratio has a very high condition of 444.8 in one company, but on ave- 
rage it is relatively good. Operational net cash flow looks good because it has a positive average, but the ratio looks small when compared to the debt ratio. This indicates that cash flows are prioritized to pay their obligations. The price earning ratio has experienced a minus, that is when the company experiences a loss. The size of the company is relatively good with equitable asset support, reaching more than USD 500 million. The age of the coal company is relatively under the age of 10 years. The average value of the exchange rate of Rupiah to Dollar is IDR 12,525.9/ USD. During the study period, the exchange rate of the Rupiah against the Dollar experienced a depreciation of $34 \%$. The average price of crude oil is USD 66.9 per barrel with USD 24.8 per barrel as a standard deviation. Crude oil prices declined by $69 \%$, precisely in 2016.

The global economy tends to be sluggish until 2017, the impact is very pronounced in developing countries such as Indonesia and causes significant fluctuations in world commodity prices. A large amount of coal supply and declining demand caused coal prices to be low, so that the operating margin of coal companies was affected. Based on Indexmundi's data, coal prices fell to the lowest level of USD 49.8/MT, equivalent to IDR 686,270.5/MT between 2013 and 2017. Coal commodity prices have an average of USD 73.3/MT. The decline in coal prices reached $52 \%$, seen in the maximum and minimum values, namely from 102.1 to 49.8 .

The decline in crude oil prices and coal prices was caused by the weakening of the global economy. China, which previously served as an economic engine for global economic growth with strong coal demand, made policy changes by reducing coal imports. Indonesia is affected by the decline in economic conditions in Europe and America despite the growth of Indonesia's Gross Domestic Product. China's policies to limit annual coal production resulted in reduced local supply and increased demand for imports. Supply disruptions in South Africa, Russia and Colombia caused the market burden to surge and made coal prices rise to the highest level of USD $116 / M T$ in four years. Slow mining reac- tions and increased seasonal demand have affected supply shortages in China. The impact of China's policy on coal export prices produced in Indonesia and Australia is expected to continue in the future.

\section{Discussion}

Tabel 2. Descriptive Statistic on Coal Sector Companies in 2013-2017 ( N=55)

\begin{tabular}{ccccc}
\hline Variabel & Coefficient & $\begin{array}{c}\text { Std. } \\
\text { Error }\end{array}$ & t-Statistic & Prob. \\
\hline ROA & 1.32530 & .59400 & 2.23113 & .0320 \\
DER & -.04583 & .08447 & -.54260 & .5907 \\
FCF & .07203 & .25029 & .28780 & .7751 \\
SIZE & .15577 & .24918 & .62514 & .5358 \\
AGE & .53461 & .51760 & 1.03285 & .3086 \\
KURS & 3.06306 & .71095 & 4.30837 & .0001 \\
OIL & .60597 & .26005 & 2.33022 & .0255 \\
HKM & .23536 & .64658 & .36400 & .7180 \\
Constantan & -45.3596 & 15.4301 & -2.93968 & .0057 \\
\hline R-Squared & .73988 & & & \\
Prob & & & & \\
(F-Statistic) & .00000 & & & \\
\hline
\end{tabular}

a. Dependent Variable: DPR

The estimation results of Table 2 show that the model has R-Squared at $73.98 \%$, the remaining $26.02 \%$ is explained by factors outside the model. The probability of F-statistics for the efficiency model has a significant effect on 0.00000 so that this value is smaller than the standard error of $5 \%$. These results indicate that all variables ROA, DER, FCF, SIZE, AGE, HKM, KURS, OIL have a simultaneous effect on DPR variables.

Return on assets in coal subsector showed similar results in previous studies (Oza, 2004; Baah et al., 2014; Frangky 2015; Benavides et al., 2016), namely return on assets had a positive and significant effect on the ratio of dividend distribution. This shows that the company's investment capability in generating profitability will affect dividend distribution. This is in accordance with the information content hypothesis theory, that return on assets (profitability) shows the company's performance in generating profits by utilizing company assets and changes 
in return on assets to be a sign of changes in dividend policy for investors. In 2013, return on assets in the coal subsector companies had an average of $8.87 \%$ with an average dividend payout ratio reaching $30.51 \%$. The following year, the return on assets fell to $4.58 \%$, followed by a decrease in dividend payout ratio.

Debt ratio has a negative and not significant effect (Deshmukh et al., 2013; Strebulaev \& Yang, 2013; Moon et al., 2015). Companies with high debt ratios will earn profits in the following year, while current profits will be allocated to pay debt contracts that may be due. In addition, the distribution of company data with an average debt ratio below 1 , means that the company is able to manage the debt composition well.

Free cash flow ratio shows results that are inversely proportional to the hypothesis (not significant) or contrary to previous research (Kalcheva \& Lins, 2007; Officer, 2011; Muhlhofer \& Ukhov, 2012). This indicates that the company understands the type of investor (clientele effect theory) who expects capital gains.

Company size has a positive and insignificant influence. This is contrary to previous research which has a significant influence (Lee et al., 2013; Nurhayati, 2013; Putri, 2013; Frangky 2015). Company's age shows results that are similar to company size and contrary to previous research (Darmawan, 2008; Takhtaei \& Tami$\mathrm{mi}, 2014)$. Companies in the coal subsector in this study were dominated by companies that were still in a growth position. The dominance of companies with assets above USD 1 million is $27 \%$, the rest are companies with assets below that. This shows that there are still companies with growth positions that are able to distribute dividends with global economic uncertainty. The aim of these small companies is to attract many investors who will have an impact on the value of the company even though the profits generated are small. However, not all of them are like that. There are some companies in the position of growth while still investing.

The exchange rate of Rupiah against Dollar and Crude Oil Price have a positive and significant influence (Suswenty, 2017). In accordance with the previous statement, that coal company in Indonesia are oriented to the export market. When there is an increase in the exchange rate (the depreciation of Rupiah against Dollar), it will increase the company's profits. Oil is a commodity that is widely used in various business fields. Its significant effect on the dividend distribution ratio shows that many coal subsector companies in Indonesia carry out efficiency strategies from the operational side of the company. At the same time, many companies reduce their production due to weather factors that do not allow mining activities. This causes oil consumption to decrease as well as cheap oil prices, causing company profits to increase because the company continues to sell the remaining coal production, so companies with small profits try to distribute dividends to attract investors as a means of adding company capital. Oil is used not as a substitute for coal, but as a support for operational activities as a reference for fuel oil. Coal produced is widely used as a power plant, so the benefits are different from the use of world crude oil.

Coal prices that have no significant effect indicate that the strategies implemented by coal companies in Indonesia in efficiency to increase company profits are considered successful so that the decline in coal prices does not affect the decline in corporate profits. In addition, the decline in coal prices caused coal companies to try to increase their sales. This is because even though Chinese demand has declined, demand from Southeast Asian countries such as Vietnam has increased.

\section{CONCLUSIONAND RECOMMENDATION}

The results of the study show that the dividend payout ratio in the coal sub-sector is influenced by the variables return on asset, exchange rate, and oil price. This result has a positive and significant effect on dividend policy in the coal subsector. The results also show that all independent variables in the two subsectors simultaneously affect the dividend payout ratio. 
Coal industries oriented to export activities will be very sensitive to changes in exchange rate of Rupiah against Dollar. Global economic conditions cannot be controlled by companies, but company management must be able to develop business strategies and adapt to changes in addressing these problems, such as quantity production efficiency, reducing operational costs, and increasing sales amid falling coal prices.

Dividends distributed by growth companies are a signal to investors that companies are still able to generate profits with uncertain global economic conditions. However, investors in the coal subsector are investors who still want capital gains rather than dividends. This can be seen from some results that are not significant to the ratio of dividend distribution. The company fully understands the character of its investors, so that it pays more attention to aspects that will increase its value, such as stock prices. For investors who still want dividends, it is recommended for mature companies with large assets, because they are more regular in dividend distribution.

This research was conducted by looking at the ratio of dividends as a proxy for dividend policy for coal subsector companies. The results found that of the eight variables only three had significant. Further research is expected to be able to do more specific searches that have not been able to be explained in this study because of the limitations of the study. Future studies can examine the condition of the dividend distribution ratio when there is a stock repurchase and stock split with the addition of a more recent research period.

\section{REFERENCES}

Abhyankar, A., Xu, B., \& Wang, J. (2013). Oil Price Shocks and the Stock Market: Evidence from Japan. The Energy Journal, 34(2), 199-222.

Abiprayu, K. B., \& Wiratama, B. (2016). Does CEO's Hubris Affecting Dividends Payout?. Jurnal Dinamika Manajemen, 7(1), 66-75.

Alli K. L., Khan, A. Q., \& Ramirez, G. G. (1993). Determinants of Dividend Policy: a Factorial Analysis. Finance Review, 28(4), 523-47.

Al-Twaijry, A. (2007). Dividend Policy and Payout Ratio: Evidence from Kuala Lumpur Stock Ex- change. Journal Risk Finance, 8(4), 349-363.

Baah, B. K., Tawiah, R., \& Opoku, F. E. (2014). Industry Sector Determintants of Dividend Policy and Its Effect on Share Prices in Ghana. International Journal of Economics Business and Finance, 2(5), 1-19.

Beatty, R. P. (1989). Auditor Reputation and the Pricing of Initial Public Offerings. The Accounting Review, 64(4), 693-707.

Benavides, J., Berggrun, L., \& Perafan, H. (2016). Dividend Payout Policies: Evidence from Latin America. Finance Research Letters, 17, 197-210.

Bhattacharya, S. (1979). Imperfect Information, Dividend Policy and the Bird in the Hand Fallacy. The Bell Journal of Economics, 10(1), 259-270.

Booth, L., \& Zhou, J. (2017). Dividend Policy: a Selective Review of Results from Around the World. Global Finance Journal, 34, 1-15.

Brigham, E. F., \& Houston, J. F. (2012). Fundamentals of Financial Management. New Tech Park, Singapore: Cengage Learning.

Darmawan, A. (2008). Pengaruh Ukuran Perusahaan, Usia Perusahaan, Leverage, Profitabilitas, Struktur Kepemilikan Perusahaan, Investasi, Peluang Investasi terhadap Dividen, Free Cash Flow. Jurnal Akuntansi dan Manajemen, 5(1), 1413-1425.

Deshmukh, S. (2003). Dividend Initiations and Asymmetric Information: a Hazard Model. Finance, 38(3), 351-368.

Eko, W., Siregar, B., Bambang, S., Dody, H., \& Frasto, B. (2013). Akuntansi Manajemen. Jakarta, Indonesia: Salemba Empat.

Fatoni, Y., Paramu, H., \& Utami, E. S. (2013). Determinan Struktur Modal pada Perusahaan Pertambangan Subsector Batubara dan Non Batubara yang Listed di Bursa Efek Indonesia. Jurnal Bisnis dan Ekonomi, 20(1), 1-11.

Fenandar, G. I. (2013). Pengaruh Keputusan Investasi, Keputusan Pendanaan dan Kebijakan Dividen terhadap Nilai Perusahaan. Management Analysis Journal, 2(2), 1-7.

Frangky, L. (2015). Determinan Kebijakan Dividen: Studi Empiris pada Negara-Negara ASEAN. Unpublished Thesis. Yogyakarta, Indonesia: Universitas Gadjah Mada.

Gordon, M., \& Lintner, J. (1956). Distribution of Income of Corporations among Dividend, Retained Earning and Taxes. The American Economic Review, 46(2), 97-113.

Jabbouri, I. (2016). Determinants of Corporate Dividend Policy in Emerging Markets: Evidence 
Pradana Jati Kusuma et al./ Analysis of Factors That Influence Dividend Payout ...

from MENA Stock Markets. Research in International Business and Finance, 37, 283-298.

Jensen, M. (1986). Agency Cost of Free Cash Flow, Corporate Finance and Takeovers. American Economic Review, 76(2), 15.

Kalcheva, I., \& Lins, K. (2007). International Evidence on Cash Holdings and Expected Managerial Agency Problems. The Review of Financial Studies, 20(4), 1087-1112.

Kang, K. H., Lee, S., \& Huh, C. (2010). Impacts of Positive and Negative Corporate Social Responsibility Activities on Company Performance in the Hospitality Industry. The International Journal of Hospitality Management, 29(1), 72-82.

King'wara, R. (2015). Determinants of Dividend Payout Ratios in Kenya. Research Journal of Finance and Accounting, 6(1), 48-51.

Lee, S., Seo, K., \& Sharma, A. (2013). Corporate Social Responsibility and Firm Performance in the Airline Industry: the Moderating Role of Oil Price. Tourism Management, 38, 20-30.

Majanga, B. B. (2015). The Dividend Effect on Stock Price-an Empirical Analysis of Malawi Listed Companies. Accounting and Finance Research, 4(3), 99-105.

Maldajian, C., \& El Khoury, R. (2014). Determinants of the Dividend Policy: an Empirical Study on the Lebanese Listed Banks. International Journal of Economics and Finance, 6(4), 240-256.

McSweeney, E. J., \& Worthington, A. C. (2008). A Comparative Analysis of Oil as a Risk Factor in Australian Industry Stock Returns, 19802006. Studies in Economics and Finance, 25(2), 131-145.

Miller, M. H., \& Modigliani, F. (1961). Dividend Policy, Growth and the Valuation of Shares. The Journal of Business, 34(4), 411-433.

Moon, J., Lee, W. S., \& Dattilo, J. (2015). Determinants of the Payout Decision in the Airline Industry. Journal of Air Transport Management, 42, 282-288.

Moosa, I. A. (2004). International Finance: an Analytical Approach. Sydney, Australia: McGraw-Hill.

Muhlhofer, T., \& Ukhov, A. (2012). Do Stock Prices Move too Much to be Justified by Changes in Cash Flows? New Evidence from Parallel Asset Markets. Proceedings. 29th International Conference of the French Finance Association (AFFI). January 1, 2012.

Nuhu, E. (2014). Revisiting the Determinants of Dividend Payout Ratios in Ghana. International Journal of Business and Social Science, 5(8).
Nurhayati, M. (2013). Profitabilitas, Likuiditas dan Ukuran Perusahaan Pengaruhnya terhadap Kebijakan Dividen dan Nilai Perusahaan Sektor Non Jasa. Jurnal Keuangan dan Bisnis, 5(2), 144-153.

Officer, M. S. (2011). Overinvestment, Corporate Governance and Dividend Initiations. Journal of Corporate Finance, 17(3), 710-724.

Oza, H. S. (2004). Dividend Decision: a Managerial Approach (a Study of Selected Enterprises). Executive Chartered Secretary, 40-45.

Prasetyo, T. (2013). Dividen, Hutang dan Kepemilikan Institusional di Pasar Modal Indonesia: Pengujian Teori Keagenan. Jurnal Dinamika Manajemen, 4(1), 10-22.

Putri, D. A. (2013). Pengaruh Investment Opportunity Set, Kebijakan Utang dan Ukuran Perusahaan terhadap Kebijakan Dividen pada Perusahaan Manufaktur yang Terdaftar di BEI. Jurnal Manajemen, 2(2), 1-13.

Raza, N., Shahzad, S. J. H., Tiwari, A. K., \& Shahbaz, M. (2016). Asymmetric Impact of Gold, Oil Prices and Their Volatilities on Stock Prices of Emerging Markets. Resources Policy, 49, 290-301.

Saeed, R., Riaz, A., Lodhi, R. N., Munir, H. M., \& Iqbal, A. (2014). Determinants of Dividend Payouts in Financial Sector of Pakistan. Journal of Basic and Applied Scientific Research, 4(2), 33-42.

Sim, N., \& Zhou, H. (2015). Oil Prices, US Stock Return and the Dependence between their Quantiles. Journal of Banking \& Finance, 55, 1-8.

Strebulaev I. A., \& Yang, B. (2013). The Mystery of Zero-Leverage Firms. Journal of Financial Economics, 109(1), 1-23.

Sudana, I. M. (2011). Manajemen Keuangan Perusahaan Teori dan Praktik. Jakarta, Indonesia: Erlangga.

Suswenty, L. (2017). Analisis Faktor-Faktor yang Mempengaruhi Dividend Payout Ratio Sektor Pertanian yang Terdaftar di BEI Periode 20112015. Unpublished Thesis. Bogor, Indonesia: Institut Pertanian Bogor.

Takhtaei, N., \& Tamimi, M. (2014). Relationship between Firm Age and Financial Leverage with Dividend Policy. Asian Journal of Finance \& Accounting, 6(2), 53-63.

Waseem. A., Saleh. A., Shukairi, M., \& Mahmood, N. (2011). The Effect of Dividend Policy Stability on the Performance of Banking Sector Listed on Amman Stock Exchange. International Journal of Humanities and Social Science, 1(5), 2012015. 